\title{
EFFECTS OF XYLITOL ON CARBOHYDRATE METABOLISIM IN RAT LIVER TREATED WITH CARBON TETRACHLORIDE OR ALLOXAN
}

\author{
HIROMASA ISHII, HIYORI TAKAHASHI, HIROSHI MAMORI, and \\ SABURO MURAI \\ Department of Internal Medicine, School of Medicine, \\ Keio University, Tolyyo, Japan \\ TAKESHI KANNO \\ Department of Biochemistry, School of Medicine, \\ Keio University, Tokyo, Japan
}

(Received for publication June 7, 1969)

Xylitol is a polyalcohol which is a regular intermediary product of the carbohydrate metabolism. ${ }^{1}$ Although there have been many reports on the effects of xylitol on the carbohydrate metabolism in animals and human beings, ${ }^{2+3}$ there have been few published data on the metabolic changes induced by the administration of xylitol in acute and subacute liver injury. Accordingly, studies were undertaken to investigate the effects of xylitol on the carbohydrate metabolism in the livers of rats treated with carbon tetrachloride $\left(\mathrm{CCl}_{4}\right)$ or alloxan. The findings presented here have suggested that xylitol is a good source of energy of the rats treated with $\mathrm{CCl}_{4}$ or alloxan.

\section{MATERIALS AND METHODS}

The experiments were carried out by using male rats of wistar strain weighing $150 \mathrm{~g}$. All animals were fed a standard laboratory diet and were deprived of food for 24 hours before they were killed. They were killed by decapitation at intervals. Alloxanized rats were produced by administering alloxan intraperitoneally $50 \mathrm{mg}$ per kilogram of body weight. $\mathrm{CCl}_{4}$ treated rats were produced by injecting subcutaneously $0.2 \mathrm{ml}$ of 50 per cent $\mathrm{CCl}_{4}$ (in olive oil) per $100 \mathrm{~g}$ of body weight. $\mathrm{CCl}_{4}$ injection was continued twice a week up to fourteen days. The in vitro study using labelled sugars was carried out according 
to the procedure described previously. ${ }^{*}$ The liver tissue to be studied was weighed and homogenized in 4 volumes of $0.15 \mathrm{M} \mathrm{KCL}$ in $0.05 \mathrm{M}$ nicotinamide with a glass homogenizer. The incubation medium were as follows; $0.5 \mu \mathrm{c}(0.05 \mathrm{ml})$ of glucose-u-C $\mathrm{C}^{14}$ or xylitol-u-C $\mathrm{C}^{14} ; 0.65 \mathrm{ml}$ of $0.1 \mathrm{M} \mathrm{KCL} ; 0.3 \mathrm{ml}$ of $0.2 \mathrm{M}$ potassium phosphate buffer ( $\mathrm{PH} \mathrm{7.4)}$; and $0.5 \mathrm{ml}$ of homogenate. The incubations were made in modified Warburg's flasks with a center well and the reactions were carried out for 60 minutes at $37^{\circ} \mathrm{C}$ in a shaking incubator. At the end of the incubation $1 \mathrm{ml}$ of Hyamine-10X was injected into the center well of each flask to trap the produced $\mathrm{CO}_{2}$. The reaction was stopped by injecting $0.2 \mathrm{ml}$ of $10 \mathrm{~N}$ $\mathrm{H}_{2} \mathrm{SO}_{4}$ into the main part of the flask. The flasks were then shaked in the incubator for an additional 30 minutes to collect the $\mathrm{CO}_{2}$. Hyamine-10X was transferred to counting bottles and the radioactivity was measured in a liquid scintillation spectrometer. (Nuclear Chicago Model 6725) For the liver glycogen study, another group of $\mathrm{CCl}_{4}$-treated rats was fasted for 24 hours before oral administration of $2.0 \mathrm{ml}$ of 50 per cent glucose solution followed, after approximately 15 minutes, by intraperitoneal administration of $10 \mu \mathrm{c}$ of xylitol-u-C $\mathrm{C}^{14}$ or glucose$-\mathrm{u}-\mathrm{C}^{14}$ per $100 \mathrm{~g}$ of body weight. The $\mathrm{CCl}_{4}$ was injected 24 hours prior to the administration of labelled sugar. The animals were killed by decapitation 3 hours after the administration of labelled sugar. The livers were extirpated and plunged into 30 per cent potassium hydroxide. Glycogen was isolated by the method of Good, Kramer and Somogyi. ${ }^{5}$ The radioactivity in the isolated glycogen was measured in a liquid scintillation spectrometer. The specific activity of the $\mathrm{C}^{14}$ used was $3.0 \mathrm{me}$ per $\mathrm{mM}$ for glucose-u- $\mathrm{C}^{14}$ and $3.2 \mathrm{me}$ per $\mathrm{mM}$ for xylitol$\mathrm{u}-\mathrm{C}-14$.

\section{RESULTS}

As shown in Table 1, which shows the values for the per cent of the administered doses of xylitol-u-C14 recovered in $\mathrm{CO}_{2}$ per $500 \mathrm{mg}$ of the liver, $\mathrm{CO}_{2}$ production from xylitol-u-C $\mathrm{C}^{14}$ was more marked than that from glucose-u-C $\mathrm{C}^{14}$ in controls. On the contrary, there were markedly reduced $\mathrm{CO}_{2}$ production both from xylitol-u-C $\mathrm{C}^{14}$ and glucose-u-C $\mathrm{C}^{14}$ in $\mathrm{CCl}_{4}$-treated rat liver. This tendency lasted for the first ten days which period the $\mathrm{CCl}_{4}$ injection was kept on twice a week. The $\mathrm{CO}_{2}$ production from xylitol-u-C ${ }^{14}$ was almost returned to the control level 21 days after the first $\mathrm{CCl}_{4}$ injection, whereas there was still reduced $\mathrm{CO}_{2}$ production in glucose-u-C ${ }^{14}$ group.

Table 2 demonstrates that the $\mathrm{CO}_{2}$ production from xylitol-u-C $\mathrm{C}^{14}$ was hardly decreased in alloxanized rat liver, whereas $\mathrm{CO}_{2}$ production from glucose-u-C $\mathrm{C}^{14}$ was markedly reduced. $(\mathrm{P}<0.003)$ 
Table 1

Recovery of $\mathrm{C}^{14}$ in $\mathrm{CO}_{2}$ produced from Xylitol-u-C14 and Glucose-u-C14 by Rat Liver Homogenate

$\left(\mathrm{CCl}_{4}\right.$ treated male rats, wistar strain)

\begin{tabular}{|c|c|c|c|c|}
\hline & \multirow{2}{*}{$\begin{array}{l}\text { Sample } \\
\text { No. }\end{array}$} & \multicolumn{2}{|c|}{$\begin{array}{c}\mathrm{CO}_{2} \text { production by liver } \\
\text { incubated with }\end{array}$} & \multirow{2}{*}{$\begin{array}{l}\text { Significance } \\
\text { level }\end{array}$} \\
\hline & & Glucose- $\mathrm{u}-\mathrm{C}^{14}$ & Xylitol-u-C ${ }^{14}$ & \\
\hline Control & 7 & $5.96 \pm 0.74$ & $6.88 \pm 0.95$ & $0.003<\mathrm{P}<0.05$ \\
\hline $\begin{array}{l}\text { Time after first } \\
\mathrm{CCl}_{4} \text { injection }\end{array}$ & & & & \\
\hline $22 \mathrm{hr}$ & 6 & $0.66 \pm 0.07$ & $0.71 \pm 0.27$ & $P>0.05$ \\
\hline 10 days & 8 & $0.55 \pm 0.46$ & $0.59 \pm 0.17$ & $P>0.05$ \\
\hline 21 days & 3 & $2.85 \pm 0.46$ & $5.42 \pm 1.62$ & $0.003<\mathrm{P}<0.05$ \\
\hline 35 days & 6 & $4.08 \pm 1.02$ & $5.86 \pm 1.84$ & $0.003<P<0.05$ \\
\hline
\end{tabular}

The data are expressed as \% of administered $\mathrm{C}^{14}$ recovered in $\mathrm{CO}_{2}$ per $500 \mathrm{mg}$ of liver.

(mean \pm standard deviation)

The $\mathrm{CCl}_{4}$ injection was continued twice a week up to 14 days.

\section{Table 2}

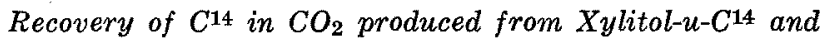

Glucose-u-C14 by Rat Liver Homogenate

(alloxan diabetic rats)

\begin{tabular}{|c|c|c|c|c|}
\hline & \multirow{2}{*}{$\begin{array}{c}\text { Sample } \\
\text { No. }\end{array}$} & \multicolumn{2}{|c|}{$\begin{array}{l}\mathrm{CO}_{2} \text { production by liver } \\
\text { inclubated with }\end{array}$} & \multirow{2}{*}{$\begin{array}{l}\text { Significance } \\
\text { level }\end{array}$} \\
\hline & & Glucose-u-C $\mathrm{C}^{14}$ & Xylitol-u-C ${ }^{14}$ & \\
\hline Control & 7 & $5.96 \pm 0.74 *$ & $6.88 \pm 0.95$ & $0.003<\mathrm{P}<0.05$ \\
\hline Alloxan diabetes & 10 & $1.70 \pm 0.95^{* *}$ & $6.77 \pm 3.28$ & $\mathrm{P}<0.008$ \\
\hline
\end{tabular}

Significance of Difference in *vs. **is $\mathrm{P}<0.003$.

The date are expressed as \% of administered $\mathrm{C}^{14}$ recovered in $\mathrm{CO}_{2}$ per $500 \mathrm{mg}$ of liver. (mean \pm standard deviation)

As shown in figure 1 , which demonstrates the data on the recovery of $\mathrm{C}^{14}$ in the glycogen of control and $\mathrm{CCl}_{4}$-treated rat liver after the intraperitoneal administration of glucose- $\mathrm{u}-\mathrm{C}^{14}$ or xylitol-u-C $\mathrm{C}^{14}$, xylitol is an efficient precursor of liver glycogen as well as glucose. Although there was a decreased glycogen 

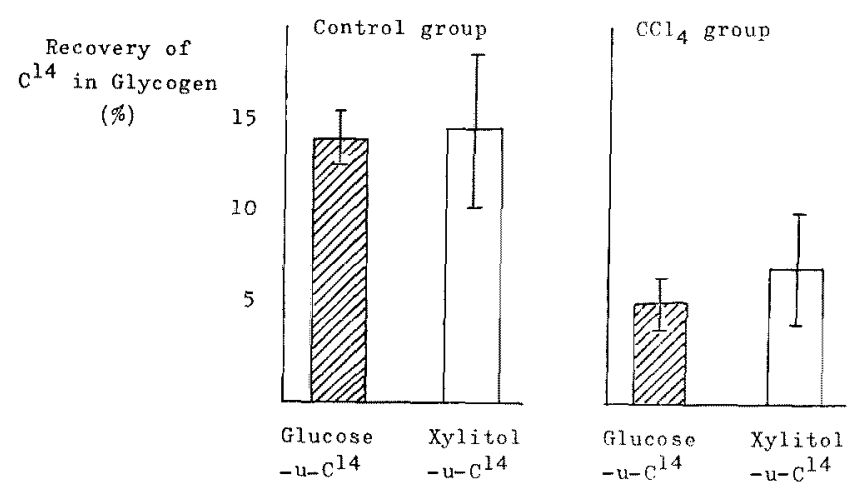

Fig. 1. Incorporation of xylitol-u- $\mathrm{C}^{14}$ and glucose-u-C $\mathrm{C}^{14}$ in rat liver glycogen.

formation from xylitol in the $\mathrm{CCl}_{4}$-treated group, the degree of decrease was less than that of glucose.

\section{DISCUSSIONS}

Xylitol is a polyalcohol which has recently been recognized as a normal intermediary product in the glucuronate-xylulose cycle. ${ }^{1}$ There have been many reports in recent years on the effects of xylitol on the carbohydrate metabolism in human beings and animals..$^{2,3,6}$ We have reported ${ }^{7}$ that blood xylitol and lactate increase after xylitol administration whereas blood sugar remains unchanged in healthy persons and in patients with diabetes mellitus or liver disease. The rapid decrease of blood xylitol level after the infusion and the small urinary loss of xylitol have also been demonstrated.7.8 These results suggest that xylitol administered to human beings can be utilized in various states such as diabetes mellitus or liver disease. In animal experiments with the use of xylitol-C ${ }^{14}$, McCormick and Touster ${ }^{9}$ have reported that the guinea pig converts xylitol-1-C ${ }^{14}$ to respiratory $\mathrm{C}^{14} \mathrm{O}_{2}$ to an appreciable extent $(10 \%)$, a portion of the polyol apparently being excreted in the urine $(25 \%)$. They have also confirmed that xylitol is an efficient precursor of liver glycogen in the rat and in the guinea pig. Schmidt $e t$ al ${ }^{10}$ have shown that after intravenous administration of xylitol-C ${ }^{14}$ 50 per cent is oxidized to $\mathrm{C}^{14} \mathrm{O}_{2}$ and the activity excreted in the urine is somewhat higher than after oral administration. The present investigation has demonstrated that in the acute stage of liver injury xylitol is as inefficiently oxidized to $\mathrm{CO}_{2}$ in the livers treated with $\mathrm{CCl}_{4}$ as is glucose. Furthermore, the data in Table 1 show that the $\mathrm{CO}_{2}$ production from xylitol-u-C ${ }^{14}$ almost returned to the control level 35 days after the first $\mathrm{CCl}_{4}$ administration, whereas $\mathrm{CO}_{2}$ production 
from glucose-u-C $\mathrm{C}^{14}$ is still below the control level. The results suggest that xylitol is more efficiently oxidized to $\mathrm{CO}_{2}$ than glucose in the livers treated with $\mathrm{CCl}_{4}$.

Fig. 1 shows the results on the conversion of xylitol-u-C $C^{14}$ and glucose- $u-C^{14}$ to liver glycogen. It is evident that xylitol is an efficient glycogen precursor as reported by McCormick and Touster. ${ }^{9}$ Furthermore, xylitol is more efficiently oxidized to $\mathrm{CO}_{2}$ in the livers of alloxanized rats than glucose $(\mathrm{P}<0.003)$. Recent studies $^{11}$ on glucose- $\mathrm{C}^{14}$ in the livers of mice treated with virus or $\mathrm{CCl}_{4}$ have shown the increased $\mathrm{C}^{11} \mathrm{O}_{2}$ production from glucose-1-C $\mathrm{C}^{14}$. These data suggest that the metabolism of glucose through the pentose phosphate cycle increases in the livers of mice treated with virus or $\mathrm{CCl}_{4}$. Moreover, there have been demonstrated $^{12}$ that the participation of the direct oxidative pathway increases relatively in the livers of alloxanized rats in spite of the decreased level of glucose-6phosphate dehydrogenase. We have reported ${ }^{13}$ that the direct oxidative pathway continues to be increased relatively in the rat livers chronically treated with carbon tetrachloride. On the basis of these findings, it may be said that xylitol, which is an intermediate in the uronic acid pathway entering the pentosephosphate cycle through D-xylulose-5-phosphate, is an excellent source of energy in the livers of rats treated with $\mathrm{CCl}_{4}$ or alloxan. It is obvious that the present data are largely preliminary and much further work is need to clarify their significance.

\section{ACKNOWLEDGEMENT}

The authors wish to acknowledge the assistance and kind considerations of Dr. Ken Sambe, professor of Internal Medicine, and Dr. Masaharu Tsuchiya, assistant professor of Internal Medicine.

Xylitol-u-C 14 used in this study was supplied by the courtesy of Eisai Co. Ltd., Tokyo, Japan.

\section{REFERENCES}

1. Hollman, S. and Touster, O. (1956) An enzymatic pathway from L-Xylulose to D-Xylulose. J. Amer. Chem. Soc. 78: 3544-3545.

2. Bässler, K. H., Prellwitz, W., Unbehaun, V. and Lang, K. (1962) Xylitstoffwechsel beim Menschen. Klin. Wschr. 40: 791-793.

3. Prellwitz, W. and Bässler, K. H. (1963) Die Verträglichkeit von Xylit beim Diabetiker. Klin. Wschr. 41: 196-199.

4. Isselbacher, K. J. and Krane, S. M. (1961) Studies on the mechanism of the inhibition of galactose oxidation by ethanol. J. Biol. Chem. 236: 2394-2398.

5. Good, C. A., Kramer, H., and Somogyi, M. (1933) The determination of glycogen. J. Biol. Chem. 100: 485-491.

6. Yamagata, S., Goto, Y., Ohneda, A., Anzai, M., Kawashima, S., Chiba, M., 
Maruhama, Y., and Yamauchi, Y. (1965) Clinical effects of xylitol on carbohydrate and lipid metabolism in diabetes. Lancet ii, 918-921.

7. Ishii, H., Takahashi, H., Oda, M., Shishido, T., Tsuchiya, M. and Sambe, K. (1967) Effects of xylitol on carbohydrate metabolism, at the 10th annual meeting of the Japan Diabetic Society in Nagoya, Japan.

8. Mehnert, H., Summa, J. D., and Förster, H. (1964) Untersuchungen zum Xylitstoffwechsel bei ge zunden, leberkranken und diabetischen Personen. Klin. Wschr. 42: 382-387.

9. McCormick, D. B. and Touster, O. (1957) The conversion in vivo of xylitol to glycogen via the pentose phosphate pathway. J. Biol. Chem. 229: 451-461.

10. Schmidt, B., Fingerhut, M., and Lang, K. (1964) UUber den Stoffwechsel von radioaktiv markiertem Xylit bei der Ratte. Klin. Wschr, 42: 1073-1077.

11. Isselbacher, K. J. and Jones, W. A. (1964) Alterations of glucose metabolism in viral and toxic liver injury. Gastroenterology 46: 424-433.

12. Glock, G. E., Mclean, P., and Whitehead, J. K. (1956) Pathways of glucose catabolism in rat liver in alloxan diabetes and hyperthyroidism. Biochem. J. 63: $520-524$.

13. Ishii, H., Murai, S., Oda, M., Kanno, T., Tsuchiya, M., and Sambe, K. (1968) At the 4th meeting of Japan Society of Hepatology, Tokyo. 